\title{
ALTERNATIVE SOLUTIONS FOR URBAN HOUSING: THE CASE OF BATIKENT SETTLEMENT, ANKARA, TURKEY
}

\author{
MELIKE ATICI \\ Atılım University, Ankara, Turkey
}

\begin{abstract}
The present study is an effort to remember and reveal the potentials of Batıkent settlement which was realized in the west part of the capital city of Turkey, Ankara in 1980s. In the period after 2nd World War, big cities in Turkey, like many other countries, entered in the process of rapid urbanization under the influence of mechanization in agriculture and migration from rural to urban areas. Increase in the population of cities and scarcity of shelter brought with the emergence of squatter areas. Batıkent settlement was developed as a flagship solution to this housing problem and established a precedent with its model of implementation for future urban cohabitations. Batıkent, as a new settlement area, was initiated by Municipality of Ankara and developed a never-before-seen operational model with three main collaborators: central government, municipality and association of housing cooperatives (Kent-Koop). Separation of roles - such as passing fiscal and housing laws, providing financial support, expropriation of land, constructing technical infrastructure, establishing municipal and commercial services, preparing master plan and designing site and house plans - through these collaborators provided this new mass development project with effective, practical and economical solutions. This study will focus on how Batıkent was developed as a platform for innovation with the operational model based on dialogue between different parties. Collection of plans from master plans to layouts of apartments, meeting notes and feasibility studies documented and published by Kent-Koop will be used in this study to achieve a better understanding of the planning process of this exemplary quarter.
\end{abstract}

Keywords: Ankara, Batıkent, sustainable settlement, cooperative planning, urban design, Kent-Koop.

\section{INTRODUCTION}

Explosion in urban population is relatively a new concept for the cities in developing countries like Turkey when compared to European cities which had experienced such a process in the $19^{\text {th }}$ century with the effect of industrial revolution. The population of Turkey, which was 13 million in 1880, reached 21 million in 1950 and 45 million in 1980. Moreover, the percentage of population living in urban areas rose rapidly after World War II from 25 to 44 percent [1]. This increase in urban population caused by migration from rural to urban was not only related to mechanization of agriculture but also associated with fragmentation of agricultural areas because of inheritance and better social conditions proposed in cities. It would not be wrong to say that the problems of rapid urbanization in Turkey have begun in 1950 s, a century after European countries.

The urbanization and housing problem emerged in the big cities of Turkey revealed different solutions. While some of these solutions were developed by authorities, some of them were generated by people informally, such as squatter houses (gecekondu) which constituted another urban problem. At the first stage, scarcity of shelter being an urgent problem brought with rapid constructions aiming to increase housing quantity without considering quality of living environments. In 1974, Batıkent project emerged as the first attempt to respond the need of cheap and healthy housing in such large scale in Turkey.

The present study aims to describe some of the key issues about Batıkent settlement project, especially its original organizational and operational model carried out jointly by cooperatives, local authority and central administration agencies. In order to comprehend the necessities behind the emergence of this new settlement project, it is thought that to begin 
with urbanization process of Ankara as a newly-declared capital city, the problems of it in different periods, and developed solutions in accordance with these problems would be useful. The paper will continue with emergence of Batıkent project with its organizational model and planning principles and end up with discussing how it is possible to interpret the lessons learned from innovative experience of Batıkent with today's point of view.

In order to touch briefly, after the declaration of Ankara as the capital city of Turkish Republic on October 13 ${ }^{\text {th }}, 1923$; Ankara entered into a rapid transformation process due to the attempts to enhance the image of new capital city. Günay [2], evaluates the development process of city with three main planning periods. As the first plan of city, 1928 Jansen plan (Fig. 1) proposed a modest approach trying to incorporate social values with the values of new regime in line with the culturalist Garden City understanding. It submits a main artery in the north-south direction which connects the old town in north to the new governmental zone in south and a secondary artery providing east-west extension. It could be said that this new governmental zone called 'Yenişehir' was the first consideration of housing problem in the history of Turkish Republic. Because of the transfer of capital from İstanbul to Ankara, housing problem was peculiar to Ankara at that time and Jansen Plan solved this problem with a low-density neighbourhood comprising of garden houses. As another new settlement planned in this period, Bahçelievler district should also be mentioned as being a cooperative enterprise constructed outside of the city. On the other hand, the macroform developed by Hermann Jansen was considered for three hundred thousand population within the next 50 years; however, at the end of 1940s, Ankara started to experience a critical population pressure and a necessity for a new plan had emerged.

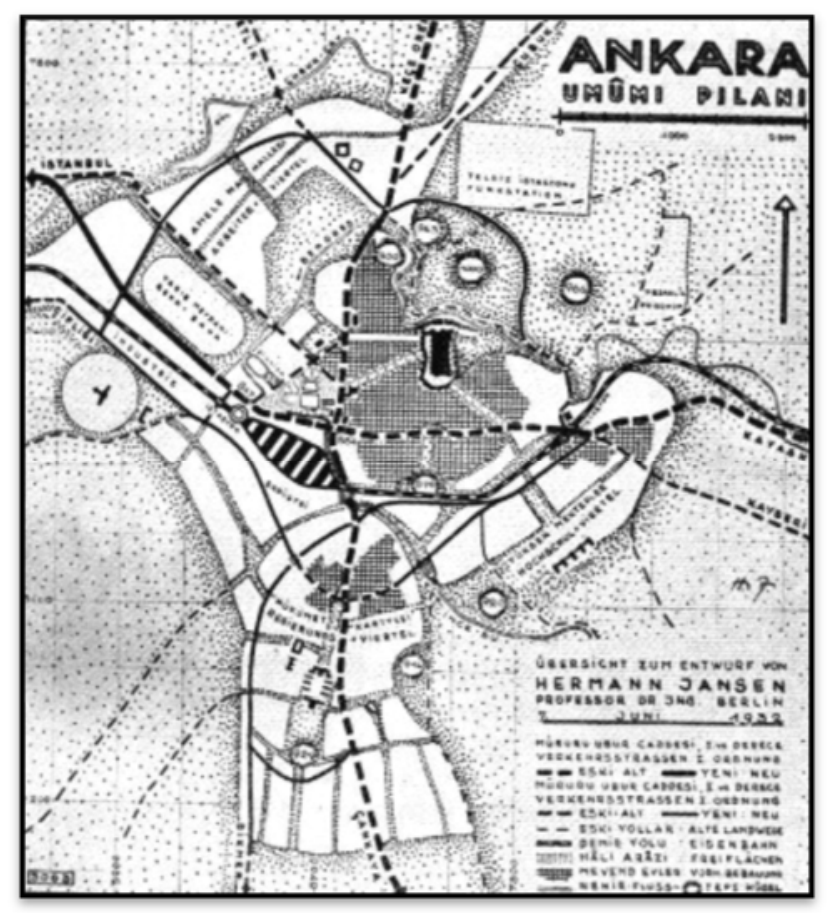

Figure 1: First plan of the capital city, Ankara. (Source: http://www.goethe.de/ins/tr/ank/prj/ urs/geb/sta/jan/trindex.htm.) 
According to statistical entries of Turkish Statistical Institute [3], the overall population of Ankara increased more than two times between 1927 and 1950, whereas the share of rural population decreased from 75.51 percent to 57.48 percent as shown in Table 1 . In 1955, a competition was organized for a new city plan and it was won by the proposal developed by Raşit Uybadin and Nihat Yücel in 1957 [2]. As the main contribution of plan, peripheral roads - two arteries towards west, one towards east, one towards north - constituting an intercity highway network could still be observed in today's Ankara.

Table 1: Ankara: Evolution of urban and rural population 1927-1980.

\begin{tabular}{|l|c|c|c|c|c|c|}
\hline & \multicolumn{6}{|c|}{ Years } \\
\cline { 2 - 7 } & 1927 & 1940 & 1950 & 1960 & 1970 & 1980 \\
\hline Rural & 305,515 & 414,549 & 471,141 & 537,529 & 574,340 & 615,722 \\
\hline Urban & 99,066 & 188,416 & 348,552 & 783,851 & $1,467,304$ & $2,238,967$ \\
\hline Overall (a) & 404,581 & 602,965 & 819,693 & $\begin{array}{c}1,321,38 \\
0\end{array}$ & $2,041,644$ & $2,854,689$ \\
\hline $\begin{array}{l}\text { Percentage of } \\
\text { rural population } \\
\text { over (a) }\end{array}$ & 75.51 & 68.75 & 57.48 & 40.68 & 28.13 & 21.57 \\
\hline
\end{tabular}

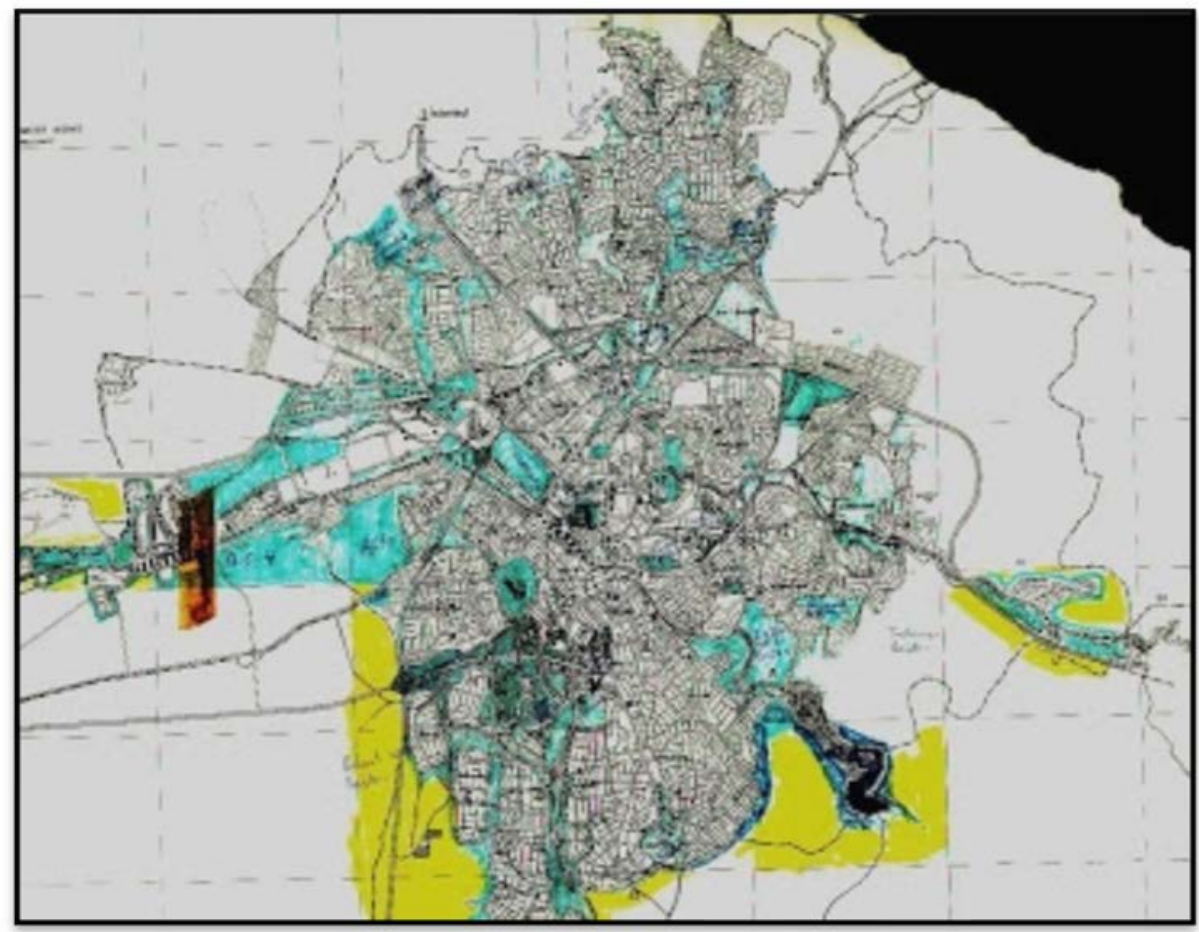

Figure 2: 1957 Uybadin-Yücel plan of Ankara. (Source: http://2.bp.blogspot.com/ _j9HNJ1Pyy_M/Sxfrg3DRv1I/AAAAAAAADI8/mzaRKAj1obk/s1600-h/Yücel UybadinPlanı.JPG.) 
Uybadin-Yücel Plan (Fig. 2) is generally evaluated as the extension of Jansen Plan whereas it continued to concern central district of the city. In order to deal with the population pressure, Uybadin-Yücel Plan paved the way for increasing the density of central north-south artery which was designed with the principles of Garden City in Jansen Plan. Thus, smallscale private developer could purchase lots in order to construct new apartment blocks and sell each unit to different owners. This 'build-and-sell' concept as a new way for housing in Turkey was also related with The Law of Property Ownership introduced in 1966. Because of the increasing density of cities and inability of local administrations to provide infrastructure for new settlement areas, the law legitimized build-and-sell housing production with allowing the ownership fragmentation in buildings. As another new mode of housing emerged in this period, squatter houses started to be built on peripheries by low-income groups and migrated population from rural to urban. These squatter houses were mostly constructed with poor quality materials without considering infrastructure. Despite their unhealthy living conditions, the housing units were in harmony with topography, the residents could control and create their own living environment within a neighbourhood relationship system which might be hard to achieve in planned housing settlements [4].

As a new settlement area planned in this period, Yenimahalle was formed in order to prevent the increase of squatter houses and unplanned development of the city. It was different from Yenişehir and Bahçelievler examples because the owners were also the constructers of their houses. The lands with ready infrastructure were given to people and each individual built their own house according to their needs [5]. However, as the city expanded, these settlements started to be parts of central city and could not preserve their original formation which was superseded by higher apartment blocks and denser character.

The last planning period mentioned by Günay was the 1990 Master Plan developed by Metropolitan Planning Office in 1970 [2]. This plan proposed a development towards western corridor with respect to natural boundaries of Ankara plain which is closed at the northern, southern and eastern edges with mountains. In order to prevent land speculation and develop solutions for squatter areas and problems of middle and low-income groups, the plan foresaw the placement of squatter prevention zones, new housing developments and industrial zones on this western corridor [6]. In this respect, it would not be wrong to say that it offered a development strategy rather than a macroform proposal. In parallel with the decisions taken in this plan, the idea of creating a new settlement on the west side of the city emerged. With all the experiences gained from previous projects, the intention to form a new town revealed the outstanding example of Batıkent with its scale, organization and construction method, and planning process.

These three Ankara plans mentioned above are critical for this study in order to understand the situation of the city at that time, the reasons necessitated new plans for the city, and accordingly, development process of Ankara. In most general words, in 1970s, increased population, rapid urbanization and squatter areas were main problems of the city. Therefore, in order to solve housing problem, developing new settlement areas especially for low and middle-income groups was one of the major concerns of that time. Hereafter, this study will continue with investigating Batıkent project as an alternative solution to housing problem.

\section{PLANNING A NEW SETTLEMENT: BATIKENT}

Batıkent (which corresponds to West-Town in English) as a mass development project was located on the Ankara-İstanbul highway at $11 \mathrm{~km}$ from the city centre, covering an area of 10,5 million sq.m. surrounded by Atatürk Forest Farm in the west, Ostim industrial area in the north-east and a strip of small industries in the south (Fig. 3). In 1974, the project was initiated by social democrat mayor (1973-1977) of Ankara, Vedat Dalokay, who was also an 
architect. He proposed a vast housing development programme to be achieved through expropriation of a large area on the west of the capital city in order to orient the urban development in accordance with 1990 Master Plan [7]. Before going inside the formation process of Batıkent, it would be necessary to mention the political atmosphere of that time. At the beginning of 1970s, Turkey experienced an indirect military intervention - coup by memorandum - to end a period of terrorism and political instability. In the period from 1971 to 1980 military coup, Turkey had two general elections, both of which concluded with coalitional majorities of two political parties: Bülent Ecevit's centre-left Republican Peoples Party (CHP) and Süleyman Demirel's centre-right Justice Party (AP). Although Turkey could not achieve stability through general elections, 1973 local elections concluded with the victory of CHP in most of the cities including the biggest cities (Ankara, İstanbul, İzmir) of Turkey by way of Ecevit's contact with non-elite masses and new poor arrivals to major cities. Accordingly, CHP municipalities approached local administration with a new understanding called 'socialist municipalitism' [8].

Being one of the prominent actors of this socialist approach, Mayor Dalokay, in order to regulate the social structure and to provide housing for low-income new immigrants, advocated the establishment of housing cooperatives gathered under the roof of Kent-Koop (Association of Housing Cooperatives). In spite of being the centre of decision-making and administration, the Municipality of Ankara preferred to play the role of helping and liberating hand in the operational model of Batıkent. At this stage, it would be useful to depict the organizational structure comprising of municipality, housing cooperatives, and central government and planning principles developed to achieve a healthy environment in Batıkent.

\subsection{Organizational structure of Batıkent}

The division of labour through three main collaborators of Batıkent project (Fig. 4) was determined as following: central government would introduce required fiscal and housing laws, providing financial source for all expanses of infrastructure construction and partly of housing construction; municipality would allocate site, construct technical infrastructure (water, sewage, roads), provide green areas and ensure the social infrastructure such as

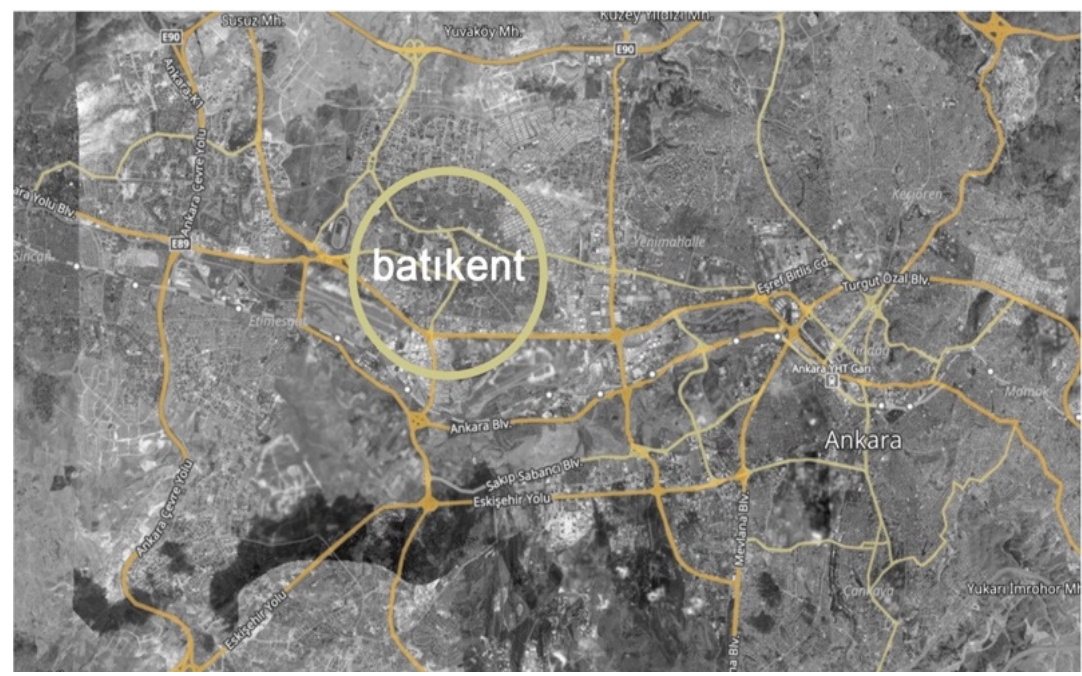

Figure 3: The place of Batıkent in the city of Ankara. (Source: Rendered by author.) 
educational and health facilities; and lastly, Kent-Koop would organize the demands of different cooperatives, prepare the master plan, architectural and engineering designs of houses, order building production mechanisms and maintain control of each actor involved in the process.

In terms of financial sources, Murat Karayalçın [9], who was the president of Kent-Koop between 1981-1991 and the mayor of Ankara between 1989-1993, says that a never-beforeseen approach was developed for Batıkent: Kent-Koop made a small amount of payment to the municipality for site; thus, financial burden on municipality was suppressed. On the other hand, for construction expanses, Kent-Koop was expected to obtain credits from foreign and domestic sources apart from the source provided by the solidarity of different civil organizations such as trade unions, associations and professional chambers. However, this model could not be a long-lasting solution. After the military coup realized in 1980, change in government brought with lacking the funds which should have been made by the State and only the local authority left as the supporter of the project. It would not be wrong to say that, under favour of Kent-Koop with its more than 200 associate cooperatives, Batıkent was completed as a self-sustained project.

To mention the inner-organizational system of Kent-Koop as depicted in Fig. 5, it constituted a non-governmental organization whose decision-making bodies were formed by the elected members of associate cooperatives. The general assembly, made up of three delegates from each cooperative, was the main decision-making body of Kent-Koop with annual meetings for operational and organizational discussions. Every four year, general assembly elected eleven members (three of whose constituting executive committee) of board of directors and three members of board of auditors. Kent-Koop with its different professional departments, such as administrational, financial, architectural and technical units, provided services to each associate cooperative [10].

\subsection{Planning principles}

The initiative works started in 1974 was completed in 1979 with expropriation of area and preparing of development plan for the new settlement. The construction of project was started in 1981 and first settlement comprising of 516 housing units settled in 1983. Whereas half ofthe total area was planned to allocate houses, the other half was intended for physical, social and other spatial needs of a settlement of 250.000 people [11]. The development plan of Batıkent was prepared according to some principles in order to achieve a well-ordered

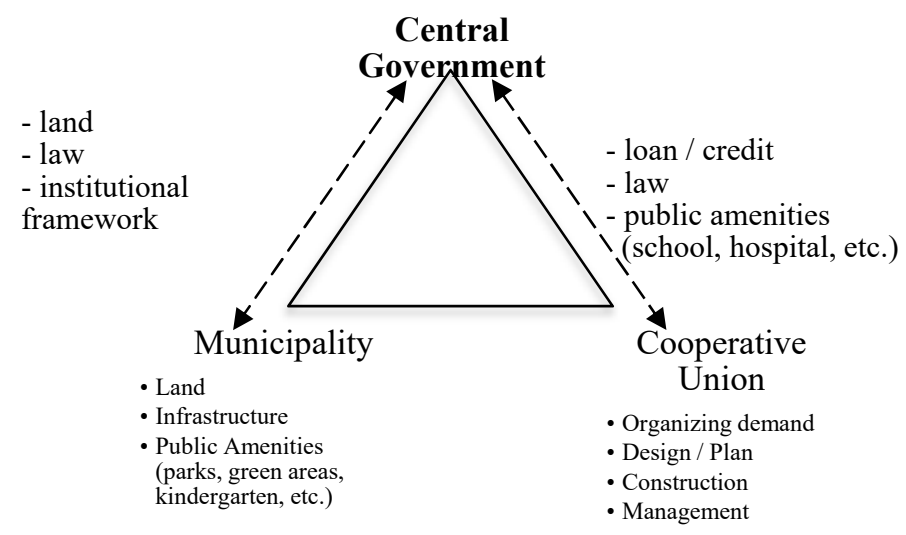

Figure 4: Organization model of Batıkent. (Source: Rendered by author.) 


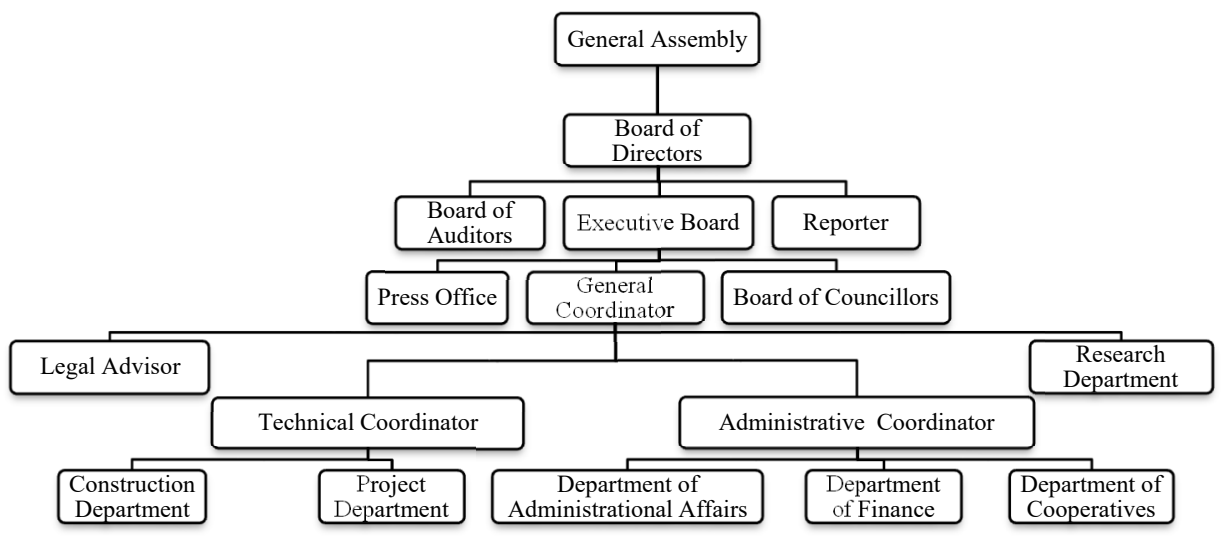

Figure 5: Organization Chart of Kent-Koop. (Source: Rendered by author.)

environment. In respect to this plan, Batıkent comprises of five different-scale units identified with varying characteristics.

The smallest unit for Batıkent was determined as a 'cooperative block' consisting 300 housing units with a social centre for commercial activities. Above the cooperative block, 'neighbourhood level' was identified with the facility of nursery. Two neighbourhood units constituted the 'quarter unit' which includes a primary school, parks, playgrounds and piazzas. 'District unit' formed from five quarter units was characterized by a high school and a subcenter serving to 50,000 people. As the largest unit containing whole settlement, 'main centre' was able to serve all Batıkent with commercial activities, religious units, social and cultural centres. In total, Batıkent was developed with 40 nurseries, 20 primary schools, 4 high schools, 4 health centres and several social and commercial units in proper for 250,000 people.

On the other hand, in order to control the density, the concentration of zones was predetermined as delineated in Fig. 6. Whereas high-rise apartment blocks of brown concentrated area were located around the main centre, orange-coloured medium concentration area encircled the brown zone. Lastly, low-rise units symbolized with yellow colour were placed along the periphery of Batikent. To mention representations of other colours; red zone refers to commercial areas, white zone with purple stripe refers to craft production, purple zone refers to industrial areas, blue zone refers to social facilities and green zone refers to parks.

In parallel with these concentration zones, residential units in Batıkent were limited with two types (Fig. 7): duplex houses with small gardens and multi-storeyed (five or ten storeys) apartment blocks. While multi-storeyed blocks were settled by middle-income families, duplex houses were constructed mostly for new arrivals of the city. The reason behind this distinction, as explained in [12], was mostly about approaching housing problem as a social and urban problem. In order to facilitate immigrants' adaptation to urban conditions, instead of a sharp change, it was intended that duplex houses with gardens would provide a suitable environment for the lifestyle, which they were accustomed to, through maintaining their relationship with land. At this juncture, it should be mentioned that in the publications of Kent-Koop, these duplex houses named as 'tidy houses' (Figs 8, 9), referring ordered versions of squatter house settlements. Another critical point behind this envisagement was 
the aim of developing a heterogeneous social composition to avoid social and economic segregation. To sum up, the planning principles regulating the formation of Batıkent mainly aim developing qualitative solutions to housing problem, as well as considering quantitative aspects.

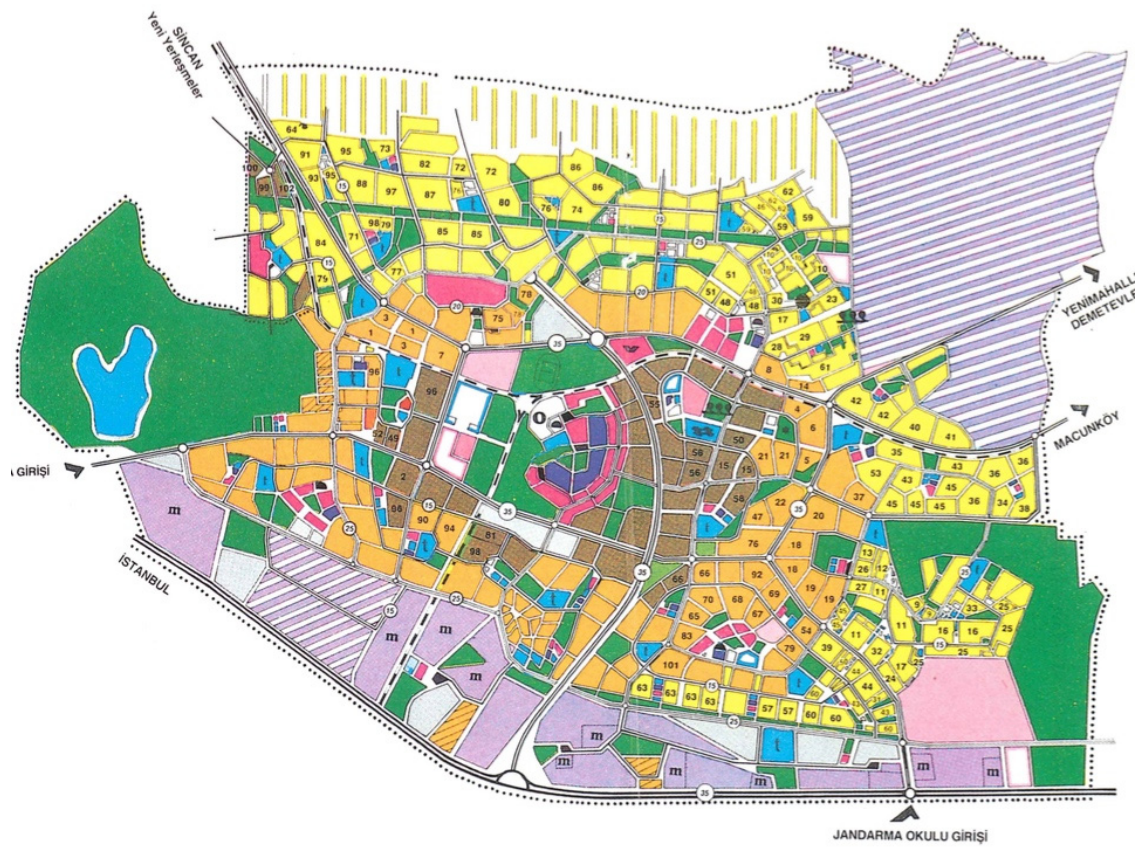

Figure 6: Site plan of Batıkent. (Source: https://archnet.org/system/publications/ contents/2949/original/DPT0592.pdf?1384768990.)

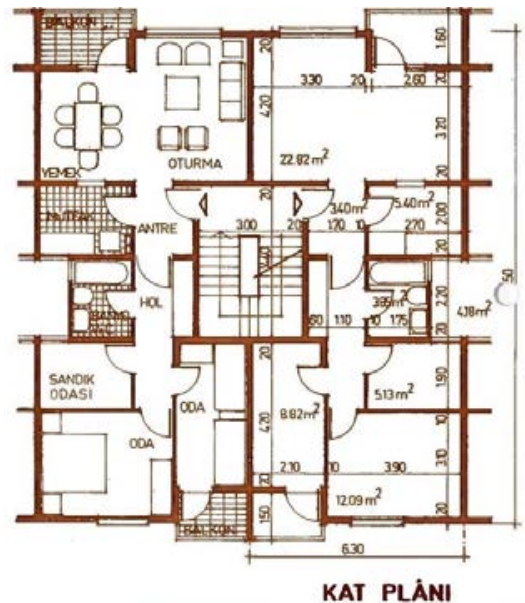

(a)

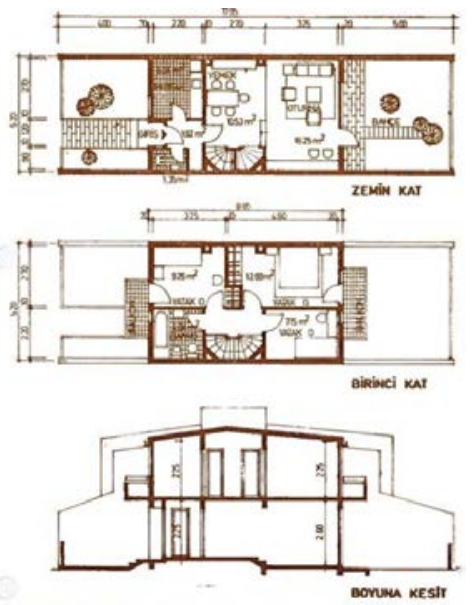

(b)

Figure 7: Sample plans of different housing types constructed in Batıkent. (a) Plan of an apartment; (b) Plans and a longitudinal section of a duplex house with garden. (Source: Archive of MESA Construction Company.) 


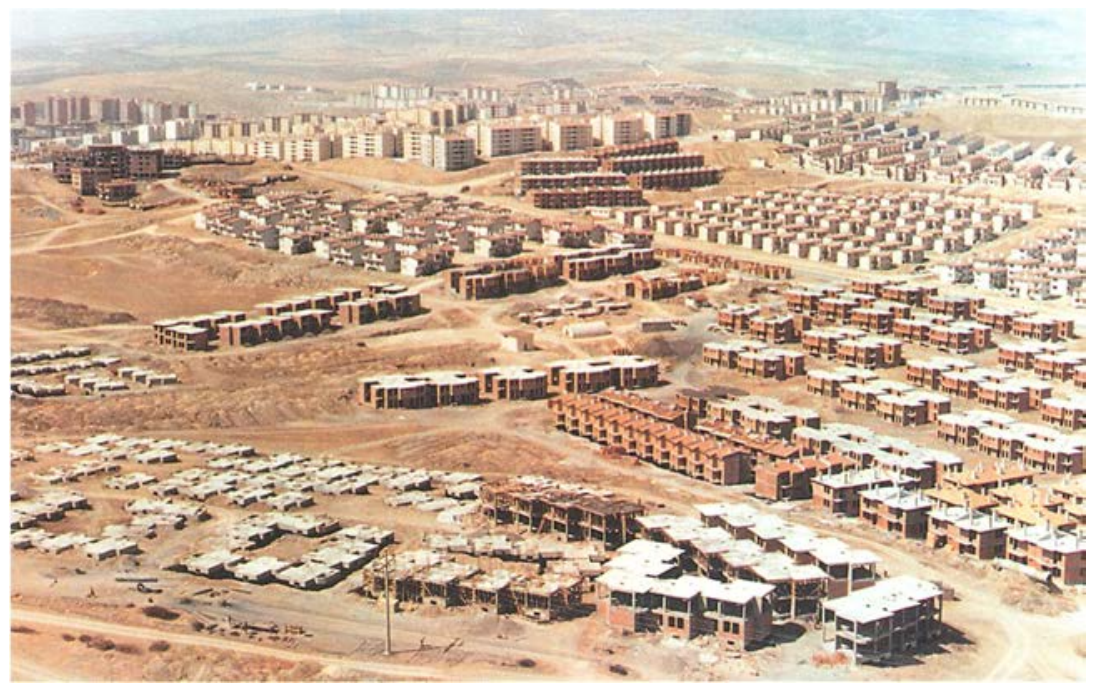

Figure 8: Aerial view of Bat1kent in late 1980s. (Source: https://archnet.org/system/ publications/contents/2949/original/DPT0592.pdf?1384768990.)

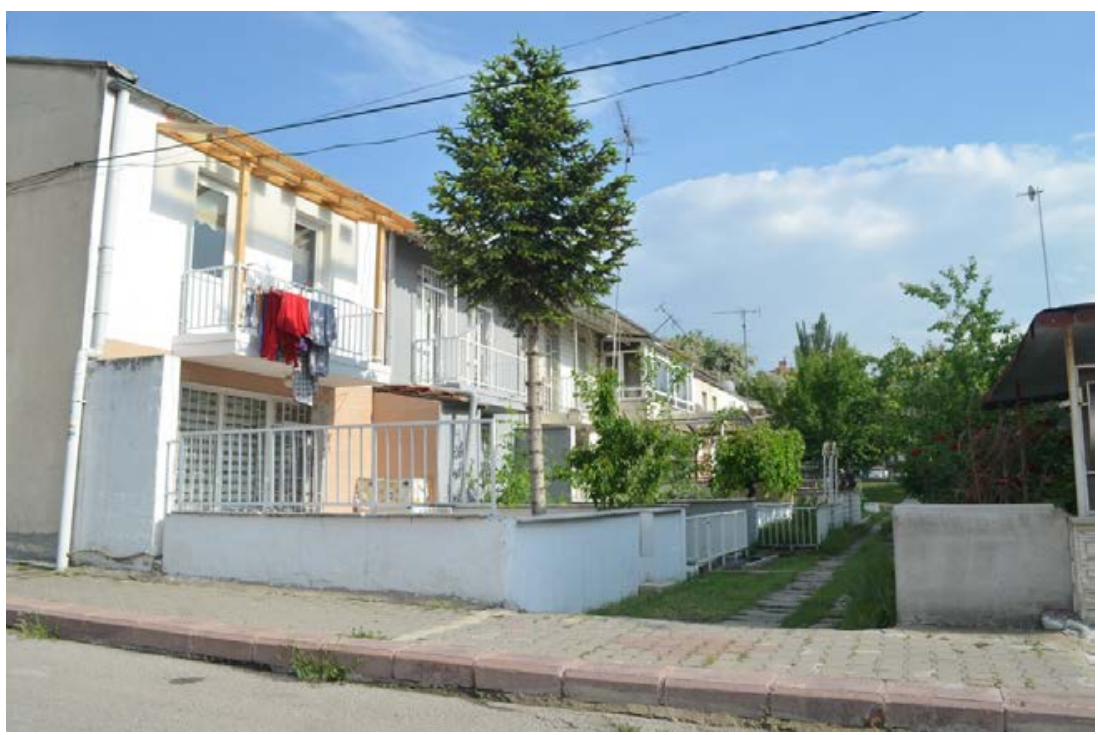

Figure 9: Current situation of Bat1kent. (Source: Photographed by author.)

\section{CONCLUSION}

It could be undoubtedly said that Batikent as an outstanding example proposed more than housing to urban housing problem. With three main collaborators - central government, municipality and association of housing cooperatives, it demonstrated the success of public and private partnership in the field of housing in Turkey for the first time. Batıkent project drew its strength from the solidarity, especially of cooperatives gathering people together to 
decide for themselves about the characteristics of houses, involve in the implementation process and meet their social and cultural needs through their own organizations. In this way, variations in building designs could have been made and the problem of monotonous environment could have been prevented. Under favour of cooperatively working, the project accomplished to organize real sufferers of housing problem and create a qualified urban sector through the democratic participation of public. Batıkent's new model having the aspiration of developing participatory and democratic project was explained with more than 40 publications (housing yearbooks, housing sector reports, books, monthly newspapers, etc) of Kent-Koop in order to set a precedent for following mass development projects realized in different cities of Turkey in 1980s. This national success of Kent-Koop on Batıkent project was awarded International Year of Shelter for the Homeless 1987 which was organized by UK Building and Social Housing Foundation [13].

If what Engels said about the urbanization is remembered, we see that he highlighted the overwhelming conditions suffered by low-income groups "The result is that the workers are forced out of the centre of the towns towards the outskirts; that workers' dwelling, and small dwellings in general, become rare and expensive and often altogether unobtainable, for under these circumstances the building industry, which is offered a much better field for speculation by more expensive dwelling houses, builds workers' dwellings only by way of exception" [14]. Since these sentences were written in 1872, there is not much change in the conditions of low-income groups. Problem of housing, as not being particular to a certain geography or time period, is still one of the most prominent matters of today's cities. The model developed for Batıkent, although it has turned into a settlement favoured by upper-middle and highincome groups and being considered among the top-choice residential areas in today's Ankara with respect to changing policies, could be evaluated as one of the possible answers of Engels' housing question.

It has passed more than 30 years since the building of first houses in Batıkent which presents the opportunity of evaluating whether it could become a successful urban development or not. However, evaluation of current environment with social and physical aspects would be the matter of a different study. What is critical for this one is the liberating aspects of the overall system applied in Batıkent and its power to organize people to take an active role for having a proper living environment without abandoning the housing issue to goodwill of private enterprises.

\section{ACKNOWLEDGEMENTS}

This study was based on the research and discussions carried out in the architectural history graduate course titled 'AH 544: Architectural History Research Studio - The Modern Capital City, Ankara 1950-1980' instructed by Prof. Dr. T. Elvan Altan in METU, in 2016-2017 academic year, spring semester.

\section{REFERENCES}

[1] Pamuk, Ş., Economic Growth and Institutional Change in Turkey Before 1980. Understanding the Process of Economic Change in Turkey: An Institutional Approach, eds. T. Çetin, F. Yilmaz, Nova Science Publishers, Inc.: New York, pp. 3-19, 2010.

[2] Günay, B., Our generation of planners, the hopes, the fears, the facts: case study Ankara. Presented at 20 th Anniversary Congress of Scupad SS, Salzburg, Austria, 1988.

[3] İstatistiklerle Ankara 2011. Ankara Kalkınma Ajansı Web Site, Ankara, http://www.ankaraka.org.tr/tr/files/yayinlar/istatistiklerle-ankara-2011.pdf. Accessed on: 18 Aug. 2017. 
[4] Günay, B., Yeni yerleşme alanları ve çevre. Presented at Şehirleşme ve Çevre Konferansı, Ankara, Turkey, 1987.

[5] Küçük, M., Yenimahalle toplu konut üretimi için örnek olabilir miydi?. Mimarlık, 261, pp. 46-49, 1995.

[6] Bademli, R., Ankara'da kent planlama deneyimi ve ulaşılan sonuçlar. Ankara 1985'ten 2015'e, ed. İ. Tekeli, Ajans İletişim: Ankara, p. 110, 1987.

[7] Eryıldız, S., Konut sorunu ve toplu konut çözümleri. Mimarlık, 261, pp. 18-36, 1995.

[8] Barchard, D., General elections and local elections in Turkey. Electoral Studies, 3(2), pp. 206-210, 1984.

[9] Karayalçın, M., Batıkent: A new settlement project in Ankara, Turkey. Ekistics, 54(325/326/327), pp. 292-299, 1987.

[10] Göksu, A.F., Organizing squatters in Turkey: The case of Zafertepe. Ekistics, 58(346/347), pp. 50-54, 1991.

[11] Sayın, E., New Settlement Projects with Special Emphasis on Turkey, Kent-Koop Publications: Ankara, Turkey, pp. 47-53, 1984.

[12] Tekeli, İ., Türkiye'de Yaşamda ve Yazında Konutun Öyküsü (1923-1980), Foundation of History Publications: Ankara, Turkey, pp. 61-65, 2012.

[13] Batıkent Project Turkey. MOST Clearing House Best Practices Web Site. http://www.citizenshandbook.org/unesco/most/easteur1.html. Accessed on: 21 Aug. 2017.

[14] Engels, F., The Housing Question, Progress Publishers: Moscow, former USSR, p. 20, 1979. 